\title{
THE PREPARATION AND ASSAY OF TOXIC PROTEOLYTIC PRODUCTS PRODUCING SKIN HEMORRHAGE ${ }^{1}$
}

\author{
By ROBERT L. BERG AND RICHARD A. FIELD \\ (From the Virus Institution of the Royal Caroline Institute, and the State Bacteriological \\ Laboratory, Stockholm; and the Departments of Medicine, Harvard Medical School, \\ and the Massachusetts General Hospital, Boston, Mass.)
}

(Submitted for publication December 16, 1953; accepted July 7, 1954)

In attempting to purify toxic factors in peptones, it was found that adequate methods of bioassay were lacking. In particular, methods for assaying the potency of biological preparations which increase capillary permeability or produce hemorrhage in the skin have been crude and inaccurate. Commonly, a guinea pig or rabbit is prepared by the intravenous injection of a proteinbinding (1-3) indicator; e.g., sulfonated dyes such as trypan blue (4-9), fluorescent dyes (10), radioactive dyes $(8)$, and certain metals $(11,12)$. The toxic material is then injected intradermally. An increase in capillary permeabiltiy is indicated by an accumulation of the indicator-protein complex at injection sites.

The intensity of the discoloration after intravenous dye has been estimated roughly using a + to ++++ scale $(4-6,9)$, or by measurements of diameter of the discolored area $(7,13,14)$. However, the subjective evaluation of such diffuse and irregularly discolored areas is unsatisfactory for quantitative assay.

A method is presented in this paper for quantitative assay of toxins which produce local hemorrhage after intradermal injection. The amount of hemorrhage has been measured spectrophotometrically. Dosage-response curves have been prepared and ordinates obtained which give a linear relationship and equal variance at all dosage levels. Using these ordinates a five point slope-ratio assay is described which has an error ("standard error of potency") of approximately 11 per cent. This assay method has been used to study the appearance of toxic products during the tryptic digestion of fibrin.

1 This work was supported in part by grants from the United States Public Health Service, the Milton Fund of Harvard University, and the Mallinckrodt Chemical Company.

\section{MATERIALS AND METHODS}

Materials. The "standard" against which all unknowns were assayed was the non-ultrafiltrable (71/2 per cent collodion membrane) portion of a six-hour tryptic digest of fibrin (see under Tryptic Digestion). In the standard preparation about half the total material was ultrafiltrable. Crystalline trypsin, polymyxin ${ }^{2}$ (a large polypeptide), and kallikrein ${ }^{3}$ (an insulin-free pancreatic extract) produce similar hemorrhages (15).

Injection. Only the backs of albino guinea pigs were used because preliminary work (16) established that the use of the abdominal skin introduces much greater variability of results. Animals weighing about 300 grams were depilated with barium sulfide paste shortly before injection. Test material was injected intracutaneously in a volume of $1 / 16 \mathrm{ml}$. from $1 / 4 \mathrm{ml}$. syringes with No. 27 flat bevel needles. The order and site of injection were distributed at random (17), and all materials were assigned a code number. The code was not broken until measurements had been recorded.

Indicator system. The fixation of intravenously injected dye was first tried to indicate the extent of reaction to intradermally injected material. The reactions were not well circumscribed, and measurements of diameter were difficult and variable. The fixation of intravenously injected metal was also demonstrated by quantitative metal analyses in individual skin areas, but the variability was even greater than with the dye method. It was also observed that reddish-purplish hemorrhagic lesions appeared (Figure 1) within ten minutes of injecting these fractions intradermally, which reached maximal size after fifteen to thirty minutes. The amount of this hemorrhage in each site proved to be an excellent indicator of the amount of toxin injected.

Measurements. The diameters of these hemorrhages were measured on the intact animal after exsanguination following a blow on the head. This preserved normal tension of the skin in a better fashion than was the case when the skin was removed. In order to have an objective check on these measurements, a colorimetric method was used. The skin was removed and the individual areas placed in ten ml. of $1 \mathrm{~N} \mathrm{NaOH}$ at $37^{\circ}$ for

\footnotetext{
${ }^{2}$ Polymyxin was supplied by Burroughs-Wellcome (USA).

${ }^{3}$ Kallikrein was supplied by Sterling-Winthrop Research Institute.
} 


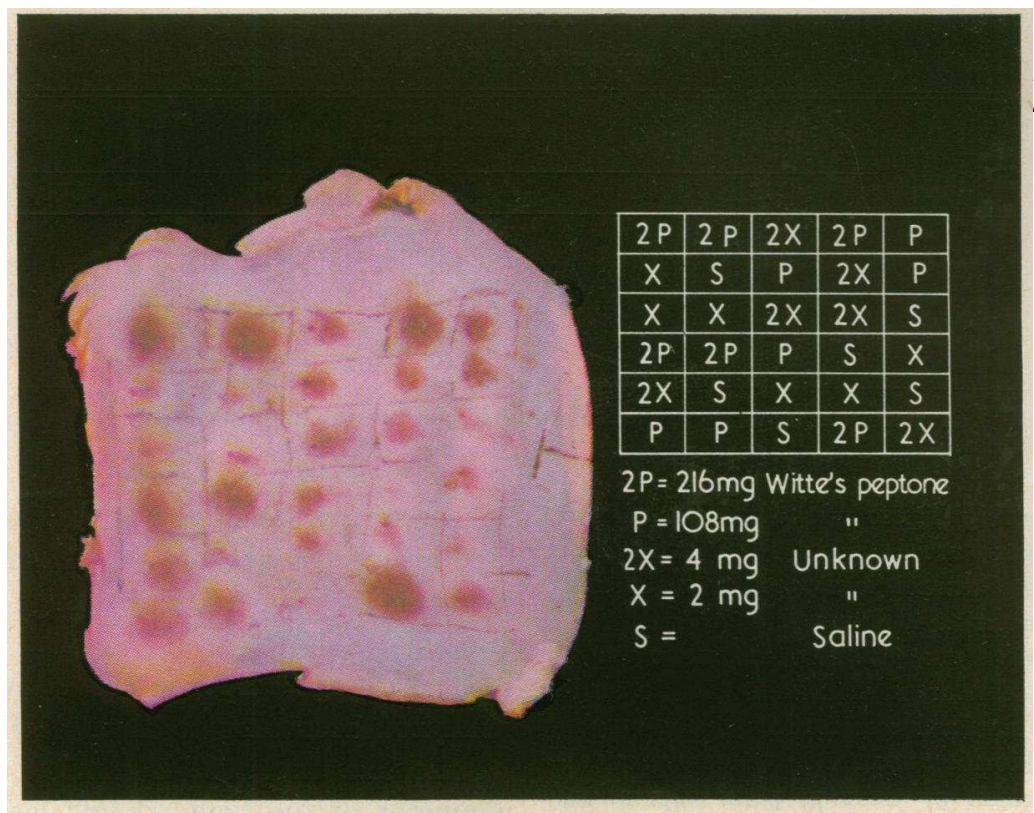

Fig. 1. Typical Arrangement for Assay of Non-Filtrable Material of Unknown Potency Obtained from Tryptic Digestion

The injections are distributed at random in space and time.

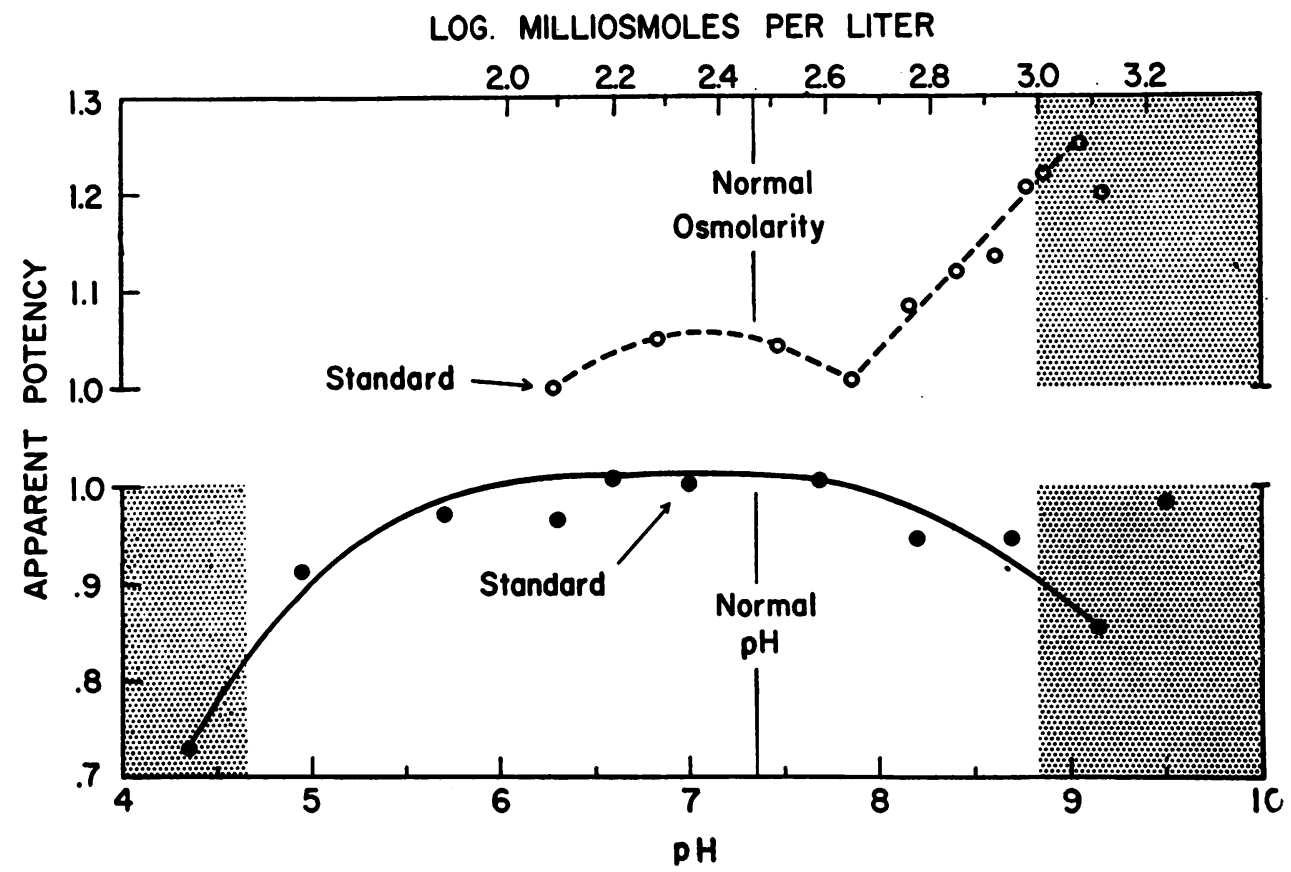

Fig. 2. Effect of pH and Osmolar Concentration on the Apparent Potency of NonFiltrable Products of a Tryptic Digest of Fibrin

In the $\mathrm{pH}$ experiment, the osmolar concentration was constant, and the $\mathrm{pH}$ of the standard was adjusted to $\mathrm{pH} 7$. In the osmolar experiment concentration of the standard was $125 \mathrm{mOs}$ per L. The shaded areas indicate the extremes where a blanched (presumably avascular) lesion appeared. The standard error of the potency determinations varied between .017 and .055 . 
TABLE I

Constitution of unknowns in 45 animal experiments *

\begin{tabular}{|c|c|c|c|c|c|c|c|c|c|}
\hline \multirow{2}{*}{$\begin{array}{c}\text { Unknowns } \\
\text { (4 injections } \\
\text { each) }\end{array}$} & \multicolumn{9}{|c|}{$\begin{array}{l}\text { Experimental groups } \\
(5 \text { animals each })\end{array}$} \\
\hline & I & II & III & IV & $\mathbf{V}$ & VI & VII & VIII & IX \\
\hline $\begin{array}{l}\text { A } \\
\text { B } \\
\text { C } \\
\text { D } \\
\text { E }\end{array}$ & $\begin{array}{l}\mathrm{S} \\
2 \\
2 \\
2 \\
2\end{array}$ & $\begin{array}{l}S \\
4 \\
4 \\
4 \\
4\end{array}$ & $\begin{array}{l}S \\
8 \\
8 \\
8 \\
8\end{array}$ & $\begin{array}{r}S \\
16 \\
16 \\
16 \\
16\end{array}$ & $\begin{array}{r}S \\
2 \\
4 \\
8 \\
16\end{array}$ & $\begin{array}{r}\mathrm{S} \\
2 \\
2 \\
16 \\
16\end{array}$ & $\begin{array}{l}S \\
2 \\
2 \\
4 \\
4\end{array}$ & $\begin{array}{l}S \\
4 \\
4 \\
8 \\
8\end{array}$ & $\begin{array}{r}\mathrm{S} \\
8 \\
8 \\
16 \\
16\end{array}$ \\
\hline
\end{tabular}

* Digits refer to concentration of "standard" peptone in $\mathrm{mg}$. per $\mathrm{ml}$. in each unknown. $\mathrm{S}=$ normal saline. Total of 900 injections, 20 to animal.

48 hours. The resulting digest was then filtered with the aid of diatomaceous earth ("super cell") and the alkaline hematin in the filtrate measured in a Coleman Junior spectrophotometer at 4000 and $4200 \AA$.

Osmolar concentration and $p H$. To determine the effect of variations in osmolar concentration (18), a single concentration of the standard was made up with varying amounts of sodium chloride at $\mathrm{pH}$ 7.0. The osmolar concentration was estimated by freezing point depression.4 Thirty-six injections were then made in each of eight guinea pigs. In Figure 2, it is evident that between 125 and $\mathbf{5 7 0}$ milliosmoles per liter there is a minimal effect on apparent potency.

Similarly, to evaluate the effect of variations in $\mathrm{pH}$, a single concentration of the standard was made up at varying $\mathrm{pH}$ but with a constant osmolar concentration (275-280 milliosmoles per Liter). Figure 2 indicates minimal effects of $\mathrm{pH}$ between $\mathrm{pH} 6.0$ and 8.0. Solutions were maintained within these limits in later experiments.

\section{ASSAY TECHNIQUE}

\section{Dosage-response curve}

The amount of hemorrhage produced with different amounts of the standard preparation was studied so that ordinates could be found which would result in equal variance at all dosage levels, as well as providing a straight line relationship in some portion of the curve. Various concentrations of the standard and of saline controls were injected in 45 guinea pigs. Each pig received twenty assorted injections according to nine different designs which combined the five different dosage levels in various ways (Table I). These different designs were used in order to rule out any possible influence of one injection area on adjacent areas, or of the response to one dosage level to influence the response to another dosage level. The analysis of these results did not indicate any

4 These determinations were provided through the courtesy of Dr. Alexander Leaf. significant tendency for the responses to one dosage level to be greater or smaller when combined with any other particular dosage levels in a given animal.

The dosage response curve and its error were analyzed according to Bliss (19). In Figure 3, at the left, the dose is plotted against both the diameter of the hemorrhagic lesions and against the spectrophotometric readings. Although a straight line is obtained with the diameters of the hemorrhage, the variance with both methods of measurement is very much greater at higher dosage levels. The variance of the direct measurement of diameters of the hemorrhage is as much equalized at all dosage levels with a square root transformation as with any other root or logarithmic transformation. A square root transformation of the dosage is needed to achieve a straight line (Figure 3, at right). The variance of the spectrophotometric readings was satisfactorily adjusted with fourth root transformation, and a linear function obtained by raising the dosage to the 1.3 power. These manipulations used to obtain a straight line and equal variance at each dosage level greatly facilitate the assay calculations described below.

\section{Assay of potency of unknown preparations}

With the information obtained from these studies it is possible to estimate the average error that will be obtained in assays of potency (19). The standard error of the dosage response line is in response units. This standard error must be converted into dosage units, because in assay procedures it is important to know how much error there is in estimates of the dose. The standard error (response units) of the line converted to dosage units is given the symbol $\lambda$. This term may then be converted 

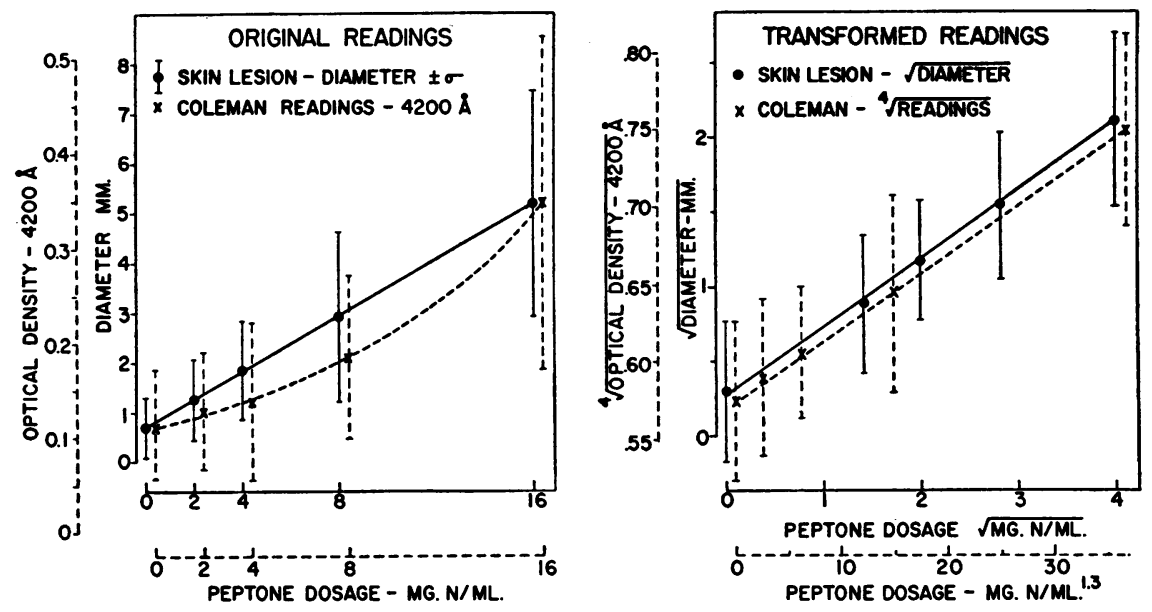

Fig. 3. Dosage-Response Curves Relating Skin Hemorrhage to Peptone Dosage

On the left are the original readings for both direct measurement of diameter, and for spectrophotometric readings of alkaline hematin present in alkaline digests of individual skin areas. The standard deviation for individual reactions at each dosage level is indicated by vertical lines. On the right, the same material has been transformed by response ordinates which roughly equalize the variance at all dosage levels, and by dosage ordinates which produce a linear function.

into the standard error of potency with the formula S.E.Potency $=2 \lambda \sqrt{\mathrm{N}}$. When thirty injections are used in a given animal, the standard error of potency can then be calculated according to this formula as indicated in Table II. After the standard error has been expressed in terms of the transformed ordinates it must be converted to arithmetic units to indicate the actual error. Thus, in arithmetic terms the standard error of potency for direct readings is about 20 per cent, and for the spectrophotometric method about 12 per cent with readings either at $4000 \AA$ or $4200 \AA$.
This expected error of assay determinations is useful if numerous assays are to be done, for one can spot repeated excessive error which may indicate carelessness or a change in technique. It can also be compared with that obtained for other assay procedures for comparing the relative efficiency of each. In Table II, the standard error of potency for a method using the measurement of diameter of hemorrhage is seen to be about the same as those obtained in measurements of diameter of tuberculin reactions (13) or of dye discolored spots (7). The objective spectrophoto-

TABLE II

Standard error of potency assuming a potency of 1.00 for different methods of measurement

\begin{tabular}{|c|c|c|c|c|c|c|}
\hline & $\lambda$ & $\begin{array}{l}\text { S.E. of } \\
\text { potency } \\
2 \lambda / \sqrt{30}\end{array}$ & $1 \pm$ S.E. & $\begin{array}{l}\text { Transformation } \\
\text { to yield arith- } \\
\text { metic values }\end{array}$ & $1 \pm$ S.E. & $\underset{\text { Error }}{\%}$ \\
\hline Direct reading & .2664 & .0973 & $\begin{array}{r}1.0973 \\
.9027\end{array}$ & $(1 \pm \text { S.E. })^{2}$ & $\begin{array}{l}+1.20 \\
-.81\end{array}$ & $\begin{array}{l}+20 \\
-19\end{array}$ \\
\hline $\begin{array}{l}\text { Spectrophotometer } \\
4000 \AA\end{array}$ & .3850 & .1406 & $\begin{array}{r}1.1406 \\
.8594 \\
1.1398\end{array}$ & $\sqrt[1.3]{1 \pm \text { S.E. }}$ & $\begin{array}{l}+1.11 \\
+.87 \\
+1.11\end{array}$ & $\begin{array}{l}+11 \\
-13 \\
+11\end{array}$ \\
\hline $4200 \AA$ & .3830 & .1398 & .8602 & $\sqrt[1.3]{1 \pm S . E .}$ & -.88 & -12 \\
\hline $\begin{array}{l}\text { Dye Method: } \\
\text { Data of Miles and Miles ( } 7 \text { ) }\end{array}$ & .273 & .0968 & $\begin{array}{r}1.0968 \\
.9032\end{array}$ & antilog $1 \pm$ S.E. & $\begin{array}{l}+1.25 \\
-.80\end{array}$ & $\begin{array}{l}+25 \\
-20\end{array}$ \\
\hline $\begin{array}{l}\text { Tuberculin: } \\
\text { Data of Wadley (13) }\end{array}$ & .264 & .0935 & $\begin{array}{r}1.0935 \\
.9065\end{array}$ & antilog $1 \pm \mathrm{S} . \mathrm{E}$ & $\begin{array}{l}+1.24 \\
-.81\end{array}$ & $\begin{array}{l}+24 \\
-19\end{array}$ \\
\hline
\end{tabular}


metric method yields an appreciably smaller error.

A five-point slope-ratio assay (20) of a particular unknown may conveniently be carried out in a single guinea pig with two dilutions of unknown, two dilutions of standard, as well as saline controls (Figure 1). An advantage of obtaining a linear function with power or root ordinates, if the line goes through zero dose, is that a sloperatio assay may be used which is more efficient than a parallel slope assay with logarithmic ordinates, because zero dose is common to both standard and unknown lines with slope ratio assays.

\section{Discussion}

The hemorrhage which is produced in skin by intradermal injection of proteolytic products is probably closely related to the escape of proteinbound dyes into these areas. The dye escape has been interpreted as indicating increased capillary permeability ever since the observation of Hoffman and Recklinghausen in 1867 (21) that cinnebar localized in an area of induced keratitis in the frog $(10,22-24)$. Erythrocytes appear in the extravascular spaces after intradermal injection of higher concentrations of many of the same toxins as promote escape of dye. The erythrocytes probably are squeezed out between endothelial cells, but no frank rupture of the endothelium has been observed in pathological sections. The induced disorder of the endothelium may then be termed increased capillary permeability or fragility, depending on whether permeability may include intercellular escape or is confined to escape through endothelial cells.

The mechanism for this erythrocyte escape is unknown, but it is known to result from the injection of hypertonic solutions locally $(25,26)$, from muscular activity alone (27), from marked tissue damage $(25,28)$, from irritant substances injected intra-arterially (29), from anaphylactic reactions (30-32), in the Schwartzman phenomenon (33), and in scurvy, hemophilia, thrombocytopenic purpura, and certain intoxications (34, $35)$. Proteolytic products may produce hemorrhage by activating tissue enzymes, in view of the observation that trypsin alone produces similar hemorrhages. However, it is possible that trypsin acts by releasing from tissue proteolytic products which are in themselves toxic,
The advantages of using the erythrocyte as the indicator in assay procedures are several. No preparative injections are needed as with the dye technique. Artificial indicators must be injected before intradermal test injections are made because increases in capillary permeability under experimental conditions are usually short-lived ( 7 , $36-38)$; furthermore, the serum level of the indicator is not constant, so that whether the dye is injected before or after the test substance, inequalities are invariably introduced.

A variety of ordinates have been used to obtain linear dosage response curves of skin reactions to various irritants $(7,13,14,39-44)$. This diversity of results compared with the present findings suggests that any of several ordinates may produce a straight line over some portion of the regression curve.

\section{TOXIN PREPARATION}

\section{Tryptic digestion}

Five hundred grams of crude commercial fibrin was washed by repeated mixing and decanting until the supernatant was free of nitrogenous material (5). The solid material was then placed in a kettle with a heating element and thermostat controlled at $37^{\circ} \mathrm{C} . \pm 1^{\circ}$. Fifty-four grams of crude pancreatic powder ${ }^{5}$ was added. Twentyfive ml. each of chloroform and toluene were added daily. This prevented any bacterial contamination as was indicated by the fact that the values for formol titration followed a smooth curve. In one experiment in which chloroform and toluene were not added daily, contamination did occur as evidenced by a foul odor and a precipitous rise in the values in the formol titration. The kettle was tightly covered and the mixture was stirred with occasional additions of pancreatic powder for a period varying from two to six weeks.

\section{Separation}

Frequent samples were taken and were kept in the cold room where they were ultrafiltered through a $7 \frac{1}{2}$ per cent collodion membrane covering an alundunum candle (45). The ultrafiltration was usually completed in the cold room after two days. The non-ultrafiltrable fraction

\footnotetext{
5 This material and certain pancreatic digestates were supplied through the courtesy of the Armour Laboratories.
} 


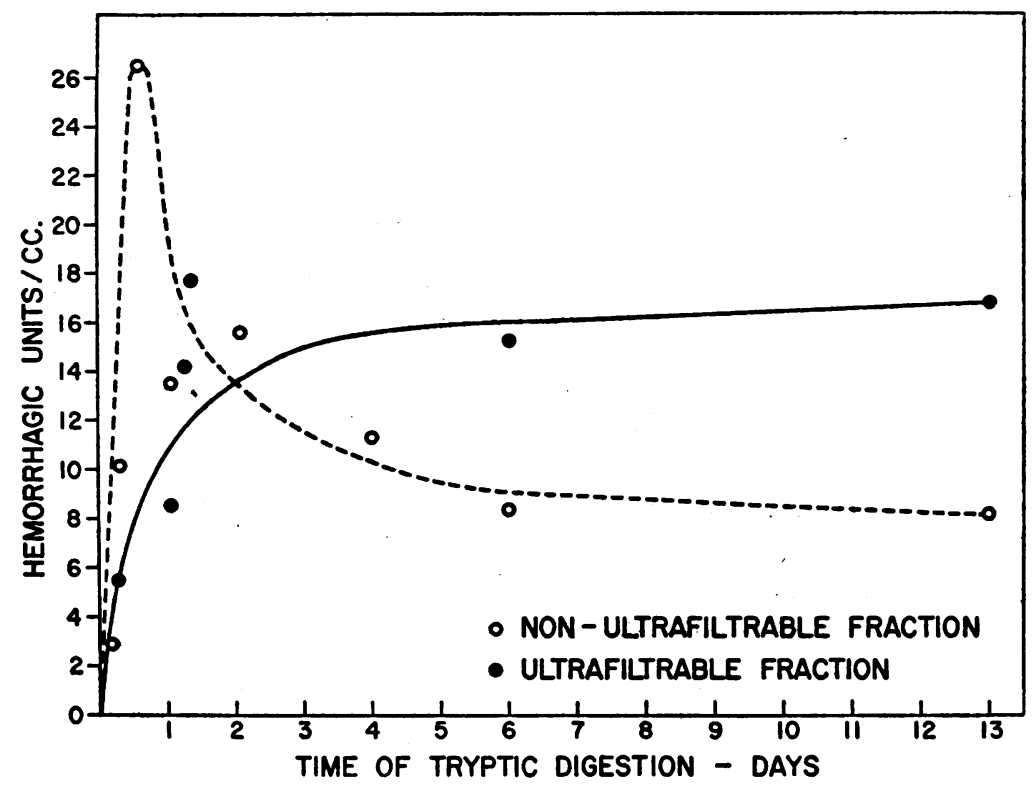

Fig. 4. The Formation During Tryptic Digestion of Ultrafiltrable and Non-Ultrafiltrable Fractions which Produce Hemorrhage ON INTRADERMAL INJECTION

The total activity of each fraction is plotted against time. Crude pancreatic powder added once at the start of digestion.

was then brought to half-saturation with ammonium sulfate to precipitate residual protein. Assays of the enzymatic activity of the supernatant (after sulfate had been removed by a second ultrafiltration) by the fibrin plate method of Astrup and Alkjaersig (46) with crystalline trypsin as the standard, indicated that less than 5 per cent of the hemorrhagic activity of the supernatant (four-hour sample) was due to non-precipitated enzyme.

Both filtrable and nonfiltrable portions were then lyophilized and used for bioassay. The appearance of toxic activity in these fractions during digestion is shown in Figure 4, in which the potency per unit volume is plotted against time. A precipitous rise in the potency of the non-ultrafiltrable material is evident which was a constant finding in numerous digestions. The potency or activity per unit weight is indicated in Table III, from which it is evident that both filtrable and nonfiltrable material retain their activity even after exhaustive digestion. The value for the nonultrafiltrable material shows considerable variability, in excess of that expected from the error of assay. This is undoubtedly due to the errors
TABLE III

The increase in potency of ultrafiltrable and non-filtrable fractions during pancreatic digestion

\begin{tabular}{|c|c|c|c|}
\hline \multirow{2}{*}{$\begin{array}{c}\text { Time of } \\
\text { tryptic } \\
\text { digestion }\end{array}$} & \multicolumn{2}{|l|}{ Potency } & \multirow[b]{2}{*}{$\begin{array}{c}\text { Formol } \\
\text { titration* }\end{array}$} \\
\hline & $\begin{array}{c}\text { Non-filtrable } \\
\text { fractions }\end{array}$ & $\begin{array}{l}\text { Filtrable } \\
\text { fractions }\end{array}$ & \\
\hline 0 & \multicolumn{2}{|c|}{$\begin{array}{l}\text { Pancreatic powder } \begin{array}{r}55 \\
\text { Fibrin }\end{array} \text { grams } \\
\text { Frams }\end{array}$} & \\
\hline \multirow{3}{*}{$\begin{array}{r}4 \text { hours } \\
7 \text { hours } \\
14 \text { hours } \\
26 \text { hours } \\
30 \text { hours } \\
33 \text { hours } \\
49 \text { hours } \\
4 \text { days } \\
6 \text { days } \\
13 \text { days }\end{array}$} & $\begin{array}{r}1.283 \\
.914 \\
6.602\end{array}$ & .1286 & $\begin{array}{l}2.01 \\
2.35\end{array}$ \\
\hline & 6.309 & $\begin{array}{l}.1282 \\
.1570 \\
.1830\end{array}$ & 3.22 \\
\hline & $\begin{array}{l}6.815 \\
4.674 \\
8.805 \\
4.477\end{array}$ & $\begin{array}{l}.1220 \\
.1257\end{array}$ & $\begin{array}{l}5.67 \\
6.94\end{array}$ \\
\hline 25 days & \multirow{2}{*}{\multicolumn{2}{|c|}{ Pancreatic powder 27 grams }} & 7.14 \\
\hline 28 days & & & 7.20 \\
\hline 31 days & \multirow{2}{*}{\multicolumn{2}{|c|}{ Pancreatic powder 25 grams }} & 7.38 \\
\hline $\begin{array}{l}33 \text { days } \\
38 \text { days }\end{array}$ & & & $\begin{array}{l}7.50 \\
7.50\end{array}$ \\
\hline 40 days & \multicolumn{2}{|c|}{ Pancreatic powder 25 grams } & 7.53 \\
\hline 41 days & 5.559 & .2021 & 7.53 \\
\hline
\end{tabular}

* The completeness of digestion may be judged by the titrable acidity after addition of formaldehyde as indicated under "formol titration." 
introduced in the course of treating these fractions prior to assay ; nevertheless, the critical point which is evident is that both filtrable and nonfiltrable fractions retain marked activity even after exhaustive digestion.

\section{Discussion}

The toxicity in the skin of enzymatic digests of protein has been repeatedly demonstrated (4, $5,9,47,48)$ although toxicity is absent in the native protein. However, no evidence has previously been available as to the time necessary for the formation and dissipation of these toxins during enzymatic digestion. The present experiments indicate that in the course of tryptic digestion, the non-ultrafiltrable fraction is progressively depleted as it is transformed to filtrable material. However, the residual nonfiltrable material gains in potency throughout digestion. The filtrable material increases both in total weight and potency during digestion.

\section{SUM MARY}

1. During pancreatic digestion of fibrin, toxic products are formed which produce local hemorrhage on intradermal injection in guinea pigs.

2. The potency and total hemorrhagic activity of the ultrafiltrable portion of the digest increases continuously until digestion is completed, i.e., the ultrafiltrable toxins are not destroyed by enzymatic digestion.

3. The potency of the non-ultrafiltrable portion increases continuously until digestion is complete, although the total activity declines asymptotically.

4. An objective and quantitative method for assaying the hemorrhagic activity is described which, in a single guinea pig, yields an assay error of \pm 11 per cent.

\section{ACKNOWLEDGMENT}

The author is much indebted to Professor Sven Gard of the Royal Caroline Institute, and to Professor Gunnar Olin of the State Bacteriological Laboratory, Stockholm, for providing facilities for initiating this work; to Professor Gard for his constant stimulation, help, and advice; and to Professor Frederick Fosteller of Harvard University for assistance with the statistical analysis.

\section{REFERENCES}

1. Bechhold, H., Kolloidstudien mit der Filtrations methode (ultrafiltration). Ztschr. f. physiol. Chem., 1907, 60, 257.

2. Friedemann, U., Parenterale Resorption in Handbuch der Biochemie des Menschen und der Tiëre, by Oppenheimer, C., 1st ed., vol. 3, pt. 2, Jena, Fischer, 1909, p. 243.

3. Gibson, J. E., Quoted in Pijoan, M., and Wheeler, S., Use of extravasating dye as a measure of skin permeability to bacterial invasion. Arch. Surg., 1937, 34, 593.

4. Cullumbine, H., and Rydon, H. N., A study of the formation, properties and partial purification of leukotaxine. Brit. J. Exper. Path., 1946, 27, 33.

5. Duthie, E. S., and Chain, E., A polypeptide responsible for some of the phenomena of acute inflammation. Brit. J. Exper. Path., 1939, 20, 417.

6. Menkin, V., Studies on inflammation: I. Fixation of vital dyes in inflamed areas. J. Exper. Med., 1929, 50, 171.

7. Miles, A. A., and Miles, E. M., Vascular reactions to histamine, histamine-liberator and leukotaxine in the skin af guinea pigs. J. Physiol., 1952, 118, 228.

8. Moore, F. D., and Tobin, L. H., Studies with radioactive di-azo dyes. I. The localization of radioactive di-brom trypan blue in inflammatory lesions. J. Clin. Invest., 1942, 21, 471.

9. Spector, W. G., The role of some higher peptides in inflammation. J. Path. \& Bact., 1951, 63, 93.

10. Lange, K., and Boyd, L. J., Use of fluorescein method in establishment of diagnosis and prognosis of peripheral vascular diseases. Arch. Int. Med., 1944, 74, 175.

11. Menkin, V., Studies on inflammation: III. Fixation of a metal in inflamed areas. J. Exper. Med., 1930, $51,879$.

12. Spagnol, G., Fattori che modificano la fissazione dei colloidi minerali nell' organismo. I. Fattori meccanici termici ed infiammatori. Biochim. ter. sper., 1927, 14, 217.

13. Wadley, F. M., The use of biometric methods in comparison of acid-fast allergens. Am. Rev. Tuberc., 1949, 60, 131.

14. Swain, H. H., and Becker, E. L., Quantitative studies in skin testing. V. The whealing reactions of histamine and ragwood pollen extract. J. Allergy, 1952, 23, 441.

15. Frey, E. K., Kraut, H., and Werle, E., Kallikrein, Padutin. Ferdinand Enke, Stuttgart, 1950.

16. Berg, R. L., The choice of skin area for toxic assay. J. Clin. Invest., 1954, 33, 1567.

17. Cochran, W. G., and Cox, G. M., Experimental Designs. New York, John Wiley \& Sons, Inc., 1950.

18. Broman, T., and Lindberg-Broman, A. M., An experimental study of disorders in the permeability of the cerebral vessels ("the Blood-Brain Barrier") produced by chemical and physico-chemical agents. Acta physiol. Scandinav., 1945, 10, 102. 
19. Bliss, C. I., Statistical Methods in Vitamin Research in Vitamin Methods. P. György, Ed., New York, Academic Press, 1951, vol. 2, p. 445.

20. Finney, D. J., The microbiological assay of vitamins : the estimate and its precision. Q. J. Pharm. \& Pharmacol., 1945, 18, 77.

21. Hoffman, F. A., and Recklinghausen, F. v., Ueber die Herkunft der Eiterköperchen. Centralbl. f. d. med. Wissensch., 1867, 5, 481.

22. Bowman, F. B., Winternitz, M. C., and Evans, H. M., Ueber die vitale Färbung des Tuberkels. Centralbl. f. Bakt., 1912, 65, 403.

23. Goldman, E. E., Die äussere und innere Sekretion des gesunden und kranken Organismus im Lichte de "vitalen Färbung." Teil 1, Beitr. Klin. Chir., 1909, 64, 192.

24. Macklin, C. C., and Macklin, M. T., A study of brain repair in the rat by the use of trypan blue with special reference to the vital staining of macrophages. Arch. Neurol \& Psychiat., 1920, 3, 353.

25. Chambers, R., and Zweifach, B. W., Intercellular cement and capillary permeability. Physiol. Rev., 1947, 27, 436.

26. Clark, E. R., and Clark, E. L., Observations on changes in blood vascular endothelium in the living animal. Am. J. Anat., 1935, 57, 385.

27. Drinker, C., Quoted in Landis, E. M., Capillary pressure and capillary permeability. Physiol. Rev., 1934, 14, 463.

28. Knisely, M. H., Eliot, T. S., and Bloch, E. H., Sludged blood in traumatic shock. I. Microscopic observations of the precipitation and agglutination of blood flowing through vessels in crushed tissues. Arch. Surg., 1945, 51, 220.

29. Broman, T., and Olsson, O., The tolerance of cerebral blood-vessels to a contrast medium of the Diodrast group. Acta radiol., 1948, 30, 326.

30. Alexander, L., and Campbell, A. C. P., Local anaphyllactic lesions of the brain in guinea pigs. Am. J. Path., 1937, 13, 229.

31. Benacerraf, B., and Kabat, E. A., A quantitative study of the Arthus phenomenon induced passively in the guinea pig. J. Immunol., 1950, 64, 1.

32. Davidoff, L. M., Seegal, B. C., and Seegal, D., The Arthus phenomenon; local anaphylactic inflammation in the rabbit brain. J. Exper. Med., 1932, 55, 163.

33. Bier, O., and Planet, N., Sur la perméabilité capillaire dans le phénomène de Schwartzman. Compt. rend. Soc. de biol., 1938, 129, 68.
34. Lever, W. F., Histopathology of the Skin. Philadelphia, Lippincott, 1949.

35. McFarland, J., A Textbook of Pathology for Practitioners and Students. Philadelphia, Saunders, 1904, p. 102.

36. Ebbecke, J. U., Capillarerweiterung, Urticaria und Schock. Klin. Wchnschr., 1923, 2, 1725.

37. Rigdon, R. H., Capillary permeability in the skin of the rabbit. Proc. Soc. Exper. Biol. \& Med., 1939, 42, 43.

38. Rigdon, R. H., Capillary permeability in areas of inflammation produced by xylene. Arch. Surg., 1940, 41, 101.

39. Bain, W. A., The quantitative comparison of histamine antagonists in man. Proc. Roy. Soc. Med., 1949, 42, 615.

40. Darsie, M. L., Jr., Perry, S. M., Rosenfeld, D., and Zaro, J. A., Size of histamine wheal in relation to dose and to animal species. Proc. Soc. Exper. Biol. \& Med., 1945, 59, 278.

41. Kahn, R. L., Studies on tissue reactions in immunity. VII. A quantitative measure of skin sensitivity. J. Immunol., 1933, 25, 295.

42. Levine, L., Wyman, L., Chen, B.-V., and Murphy, J., The quantitative determination of the extent of despeciation of modified equine antitoxin. $\mathrm{J}$. Immunol., 1952, 69, 627.

43. Plummer, H., The accuracy of the skin test in chinchilla rabbits in the determination of the strengths of streptococcal toxins and antitoxins. Brit. J. Exper. Path., 1934, 15, 80.

44. Gröer, Fr. v., Utber die zweiparametrige Betrachtung des pathergischen Geschehens und das Prinzip der Pathergometrie. Klin. Wchnschr., 1935, 14, 1094.

45. Kabat, E. A., and Mayer, M. M., Experimental Immunochemistry. Springfield, Charles C Thomas, 1948, Chapt. 33, p. 429.

46. Astrup, T., and Alkjaersig, N., Estimation of proteolytic enzymes by means of their fibrinolytic activity. Arch. Biochem., 1952, 37, 99.

47. Adlersberg, D., and Perutz, A., Untersuchungen über die Anreicherung von im Blute kreisenden Farbstoffen in Hautquaddeln. Klin. Wchnschr., 1932, 11, 942.

48. Menkin, V., Studies on inflammation. XVI. On the formation of chemotactic substance by enzymatic action. J. Exper. Med., 1938, 67, 153. 